Jurnal Ekonomi Pembangunan, 18 (2), 2017, 245-255

\title{
Green Perceived Value for Environmentally Friendly Products: Green Awareness Improvement
}

\author{
Didin Syarifuddin ${ }^{1 *}$, Doni Purnama Alamsyah² \\ ${ }^{1}$ STP Ars Internasional, \\ ${ }^{2}$ Master of Management, Universitas BSI \\ *Corresponding Author: didinars@gmail.com
}

Received: August 2017 | Revised: November 2017 | Accepted: November 2017

\begin{abstract}
This study aims to review the correlation of green perceived value and green brand attribute on green awareness with supporting moderation of customer's demographic. The review focuses on environmentally friendly products with 467 respondents who come from Supermarket's customer in West Java Province. Hypothesis test is found that green awareness can be improved through green perceived value and green brand attribute. But green perceived value plays important role in controlling green awareness. Besides that, supporting from customer's demographic (sex, location, income) also very influenced the correlation level of green perceived value, green brand attribute with green awareness. The study review is useful in reviewing green customer behavior particularly in Indonesia that has still poor of caring; and in the effort of facing global warming through the review on environmentally friendly products.
\end{abstract}

Keywords: Green Perceived Value, Green Brand Attribute, Green Awareness JEL Classification: $M 310, D 12$

How to cite: Syarifuddin, D., \& Alamsyah, D. (2017). Green Perceived Value for Environmentally Friendly Products: Green Awareness Improvement. Jurnal Ekonomi Pembangunan: Kajian Masalah Ekonomi dan Pembangunan, 18(2), 104-114. doi:https://doi.org/10.23917/jep.v18i2.5145

DOI: https://doi.org/10.23917/jep.v18i2.5145

\section{Introduction}

Customer who cares with environmentally friendly products in the world has been improving (Suki, Suki, \& Azman, 2016). It is also happened in Indonesia (Alamsyah, Trijumansyah, \& Hariyanto, 2017), so company is prosecuted to be more putting forward marketing strategy on environmentally friendly products. This caring is improved because customer is aware in the effect of conventional products that will damage environment, besides it does not make healthy for human body (Kim \& Chung, 2011). Green awareness has been sounding by customer in the world, in order to face global warming issue (Suki, 2013). So lifestyle that notices on the pattern of healthy food consumption becomes increased.
The review of green awareness becomes more interesting so it needs to be known the factor that can improve green awareness. It is known that customer's behavior for green awareness needed in improving customer's buying interest which customer trust for environmental products (Rahmi, Rozalia, Chan, Anira, \& Lita, 2017). Buying interest is the expected behavior by company that comes when offering for more expensive products (Syarifuddin, 2017). It is the same with customer trust, because through customer trust company is easier in offering its product (Alamsyah et al., 2017).

Environmentally friendly products are product that produced without chemical materials like organic vegetables or fruits (Alamsyah et 
al., 2017). This product is truly having different characteristic with conventional product. The own base character is on more expensive price (Haghjou, Hayati, Pishbahar, Mohammadrezaei, \& Dashti, 2013)and in Indonesia it is sold only in a certain place like Supermarket (Alamsyah et al., 2017). So it is needed the more effort from customer in buying environmentally friendly products. However, those cases do not become problem when green awareness from customer improved. Because customer who cares towards environment, they will do anything to encourage those concepts applied. The values of environmentally friendly products are something that becomes customer's consideration in selecting organic products (Shaharudin, Pani, Mansor, \& Elias, 2010). The value meant is free from pesticide, healthy when it is consumed and it does not damage environment. It means that customer needs the value from environmentally friendly products. Those values contained in others customer's behavior or it is called green perceived value (Lian, Safari, \& Mansori, 2016). Green perceived value is the whole of customer's assessments for environmentally friendly products which is evaluated to be good negatively and positively (Ariffin, Yusof, Putit, \& Shah, 2016). Nowadays, green perceived value becomes important attention in the relation to living environment issue. It becomes also important for company that relates to customer buying interest (Wu \& Chen, 2014). But the most important thing is known the impact of green perceived value on the improvement of customer's green awareness on the purchasing of environmentally friendly products offered by company (Wu \& Chen, 2014).

Today, green awareness not only becomes customer's behavior for environmentally friendly products. It also gives the influence on human behavior in many ways, such as reducing consumption, changing wasteful or harmful consumption patterns and raising preference for environmentally friendly products, selective waste collection, or different forms of protest that may represent ecological sensibility (Suki, 2013). In
Indonesia customer's behavior on environmentally friendly products is not as good as in developing country, it seems from customer's attention to choose organic product in Supermarket that has not been significant yet (Alamsyah et al., 2017). It is probably green attribute not attractive or it is not known by customer. In fact it is known that green brand attribute is one of customer's behavior that can grow customer green awareness (Purnama \& Nurhadi, 2014). The accurate information of green brand attribute can improve customer's view for product, especially for environmentally friendly products (Lassoued \& Hobbs, 2015). Remember the phenomenon currently is still low of customer's knowledge for green attribute in Indonesia. Reviewing from the phenomenon of green awareness's problems on organic products, the study focuses on the influence of green perceived value and green brand attribute on the improvement of customer green awareness for environmentally friendly products. Indonesia is country that consists of some provinces, even tribes and different location (urban and sub urban) (Syarifuddin, 2016). So the study also reviews supporting from moderation of customer's biography, to know more detail about the correlation between variables from customer's characteristic. The study review of green perceived value, green brand attribute and green awareness become interesting; remember it has not been reviewed simultaneously with the study of customer's biography in Indonesia.

\subsection{Green Awareness}

In buying environmentally friendly products, a customer should has green awareness behavior (Mourad, Serag, \& Ahmed, 2012). So the marketer sometimes evaluates green awareness from customer before they offer their product (Rahmi et al., 2017). The case that becomes marketer's attention is the value contained inside of environmentally friendly products through media that can be known by customer. As example on supermarket, organic product is given additional information as label and other advertisements in 


\section{Jurnal Ekonomi Pembangunan, 18 (2), 2017, 245-255}

order to be assessed by customer (Atănăsoaie, 2013). Finally, customer is aware the importance of environmentally friendly products. However green awareness does not grow in customer-self only through information given by marketer, the more decisive is customer awareness for effect of environmentally friendly product consumption (Suki et al., 2016).

Green awareness is customer behavior for buying environmentally friendly products that is followed by customer's interest to choose and consume it (Suki et al., 2016). Theoretically, it is stated that green awareness is based on recognizing and recalling the brand as a green brand as a result of the green activities and associations (Mourad et al., 2012). A thing that needs to be underlined on green awareness is green brand for product owned by company which produce environmentally friendly products. It is in line with the beginning theory from brand awareness which is stated before by Keller (1993), that brand awareness are recognize and recall the environmental features of the brand. Those cases can be assumed that green awareness positively related to green brand preference. In this study, green awareness is closely related to customer, so theory adopted by Rizwan et al. (2014) mentioned that "green awareness is expressed as a consciousness possessed by a consumer that consuming green product will contribute to give good value to the environment". So it can be known that in principle green awareness is a knowledge owned by customer for products which relates to its impact on environment. Relating to customer purchasing behaviour, green awareness can be formed by four cases which is consumers' environmental concerns, awareness of green product, awareness of price, and awareness of brand image (Suki, 2013).

\subsection{Green Perceived Value}

Each product offered by company for customer has advantage and disadvantage (Khor, Udin, Ramayah, \& Hazen, 2016). Marketing tries to give information more than its product in order to be assessed better by customer. Those values are evaluated finally by customer and it tipped on customer perceived value (Chi, Yeh, \& Jang, 2008). It is the same with environmentally friendly products like organic product which it is traded in supermarket (Ellison, Duff, Wang, \& White, 2016). It has some advantages compared with conventional product; it seems from packaging, product's shape until nutrition's information that is explained to customer. This case aims to give best assessment for environmentally friendly products that can be evaluated by customer as green perceived value. According to Chen \& Chang (2012), green perceived value is stated as "a consumer's overall appraisal of the net benefit of a product or service between what is received and what is given based on the consumer's environmental desires, sustainable expectations, and green needs". In principal, the underlined case from green perceived value relates to customer's evaluation for environmentally friendly products.

The value of organic product that changed becomes green perceived value is truly needed by marketer, especially relating to customer's interest in buying environmentally friendly product (Chen \& Chang, 2012). So many studies done to assess and evaluate customer's behavior for green perceived value (Rizwan et al., 2014). One of studies found in the previous research that green perceived value can develop well through supporting from green advertising conducted by marketer(Wu \& Chen, 2014). And also it is evaluated that green perceived value can improve customer's care for environmentally friendly products or green awareness (Wu \& Chen, 2014). Some common assessment are done on green perceived value such as good value, expectations, environmental concern, environmental friendly, and environmental benefit (Chen \& Chang, 2012).

\subsection{Green Brand Attribute}

Green brand attribute has different characteristic, there is attribute marks those 
Jurnal Ekonomi Pembangunan, 18 (2), 2017, 245-255

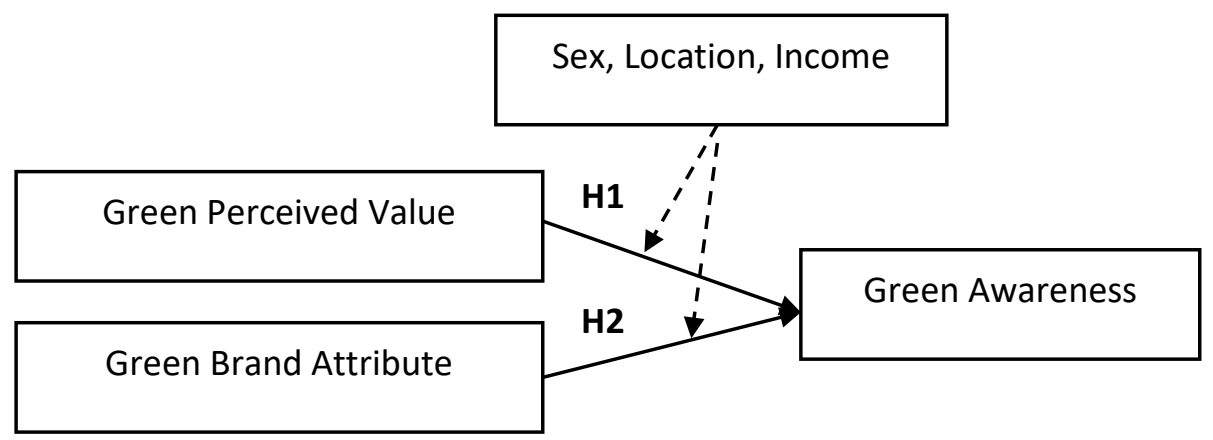

Figure 1. Research Model

products are free from chemical materials or it has organic logo (Alamsyah et al., 2017). There are others attributes that give differentiator between environmentally friendly product with conventional product (Wirth, Stanton, \& Wiley, 2011), it is common happened remember the marketer does deliberately in order to environmentally friendly products' assessment can be improved. Some attributes stated by environmentally friendly product then become self-assessment by customer who is packaged in green brand attribute (Lassoued \& Hobbs, 2015). Credibility from information inside of green brand attribute is expected can improve customer's view for quality of environmentally friendly products and marketer's image (Nikhashemi, Tarofder, Gaur, \& Haque, 2016). It is not often for green attribute becomes the important role in the process of customer purchasing decision for environmentally friendly products.

In simplicity, it is explained by Nadzri et al. (2016) that brand attribute is "information about various aspects of product characteristics that are difficult to quantify". So it can be concluded that green brand attribute is the characteristic which distinguish of environmentally friendly product assessed by customer. Every customer has different reaction with environmentally friendly product assessed by themselves (Lassoued \& Hobbs, 2015). It is fully depends on product attribute and the most important thing is support from advertising of environmentally friendly products, that sometimes it makes customer's assessment doubt for product (Yoo \& Chang, 2005). In the journey, green brand attribute can be assessed from some cases like expensive, reasonably priced, prestigious, associated with rich owners, telling the time, durable, pure or natural, rich or creamy, and tasty (Bhat \& Reddy, 2001).

\section{Research Method}

Inreviewinggreenawareness, green perceived value and green attribute from environmentally friendly products, were conducted survey on customer who came to supermarket in West Java Province with 500 respondents. It is conducted remember that organic products like vegetables or organic food is easy to be found in supermarket with some product attribute and also its product advertisement. Data from respondent reviewed through multiple regression analysis and data obtained quantitatively by questionnaire on 2017 . Questionnaire was made with Likert Scale approach through statement point which was " 1 for strongly disagree" until "5 for strongly agree". Questionnaire was made depends on some review indicators of green awareness, green perceived value and green brand attribute. First, for green awareness was measured by consumers' environmental concerns, awareness of green product, awareness of price, and awareness of brand image (Suki, 2013). Second, for green perceived value the measurement used related to good value, expectations, environmental concern, environmental friendly, and environmental benefit (Chen \& Chang, 2012). The last, for green brand attribute was assessed from some measurements like expensive, reasonably priced, prestigious, associated with rich owners, telling the time, du- 


\section{Jurnal Ekonomi Pembangunan, 18 (2), 2017, 245-255}

rable, pure or natural, rich or creamy, and tasty (Bhat \& Reddy, 2001). Analysis was conducted by research model that appeared on Figure 1.

Reviewing from Figure 1, it was stated that study reviews the correlation of green perceived value, green brand attribute on green awareness. Then, it was conducted the moderation review from customer's demographic which depends on sex, location and income. The research was conducted through hypothesis test; Hypothesis 1 (H1), Green Perceived Value had positive correlation with green awareness for environmentally friendly products. Hypothesis 2 (H2), Green Brand Attribute had positive correlation with green awareness for environmentally friendly products.

\section{RESULTS AND DISCUSSION 3.1 Research Finding}

This study aims to analyze the correlation of green perceived value and green brand attribute on green awareness that is moderated by customer's biography such as sex, location and customer's income. Research result found that 467 respondents are valid for the questionnaire. Then, those data are processed to analyze the correlation among variables. From the whole of respondents data are known that the number of respondent is balanced between female and male; it is different with customer's home location who is dominated by urban is about $65 \%$ and compared with customer who is in sub urban only $45 \%$. It is assumed most of supermarkets are in urban; it is not in sub urban. Then, customer who has busy in urban, they will be easy to interact with supermarket. Other information that is also known in this study is relating to customer's income where it is dominated by income's average between 5-10 million is about 53\%, 10-15 million is about $37 \%$ and the rest is less than 4 million, which is about $10 \%$. From customer's income, data can be known that most of customers have better buying interest for product in supermarket included environmentally friendly products which has different characteristics like more expensive price (Haghjou et al., 2013). Furthermore, data from all respondents are managed and processed through statistical application to get know the correlation among variable, the result is stated on Table 1 related to hypothesis test result and Figure 2 related to model of research finding.

Table 1. Hypothesis Test Result

\begin{tabular}{cccc}
\hline Hypothesis & $\begin{array}{c}\text { Path } \\
\text { Coefficients }\end{array}$ & t-value & Results \\
\hline H1 & 0.66 & 6.79 & Support \\
H2 & 0.16 & 3.30 & Support \\
\hline
\end{tabular}

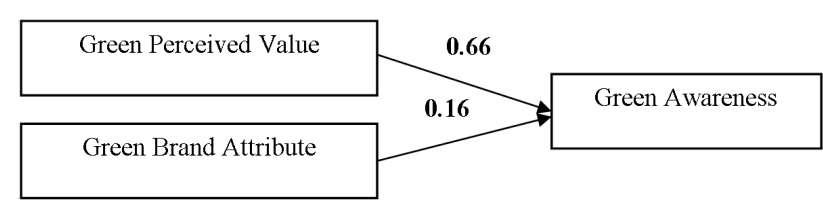

Figure 2.Research Finding

If it is known by Figure 2 that green perceived value has positive correlation with green awareness is about 0.66. This value is higher than the correlation of green brand attribute with green awareness is only 0.16. This case can be concluded that green perceived value and green brand image can truly improve customer's green awareness on environmentally friendly products. All of the correlations $(\mathrm{H} 1, \mathrm{H} 2)$ have been tested by hypothesis and its result is significant, it seems on Table 1 (Support). Next, in this study research model is reviewed based on point of view of customer's biography. That demographic meant such as sex, location, and customer's income. There are three research models depend on demographic, but the review of research model is not tested or discussed relating to the value of $t$-value to know the significance level of research finding. Remember the study is based on customer's demographic only to know the value of demographic support on the correlation of green perceived value (X1), green brand attribute (X2) on green awareness improvement (Y). Furthermore, the result of each data processing which based on customer's demographic seems on Table 2. 
Jurnal Ekonomi Pembangunan, 18 (2), 2017, 245-255

Table 2. Demographics Result

\begin{tabular}{lccc}
\hline \multirow{2}{*}{ Moderator } & \multirow{2}{*}{ Item } & \multicolumn{2}{c}{ t-value } \\
\cline { 3 - 4 } Sex & Female & 0.33 & 0.12 \\
\multirow{2}{*}{ Location } & Male & 0.87 & 0.17 \\
& Urban & 0.70 & 0.16 \\
\multirow{2}{*}{ Income } & Sub-Urban & 0.52 & 0.15 \\
& < 4 million & 0.99 & 0.04 \\
& 5-10 million & 0.46 & 0.27 \\
& $>10$ million & 0.87 & 0.17 \\
\hline
\end{tabular}

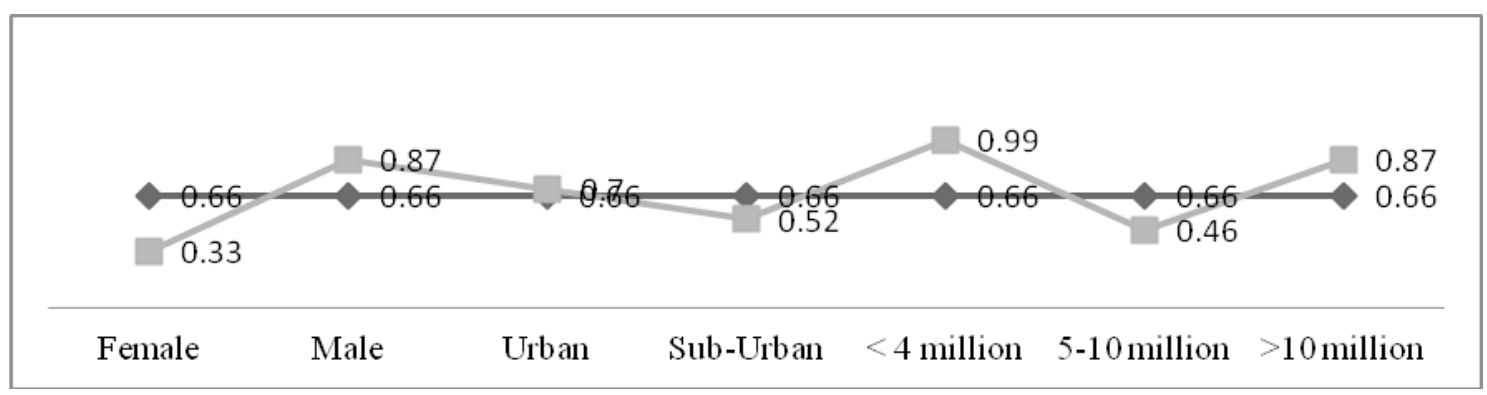

Figure 3.The Relationship Statistic X1 $\rightarrow$ Y

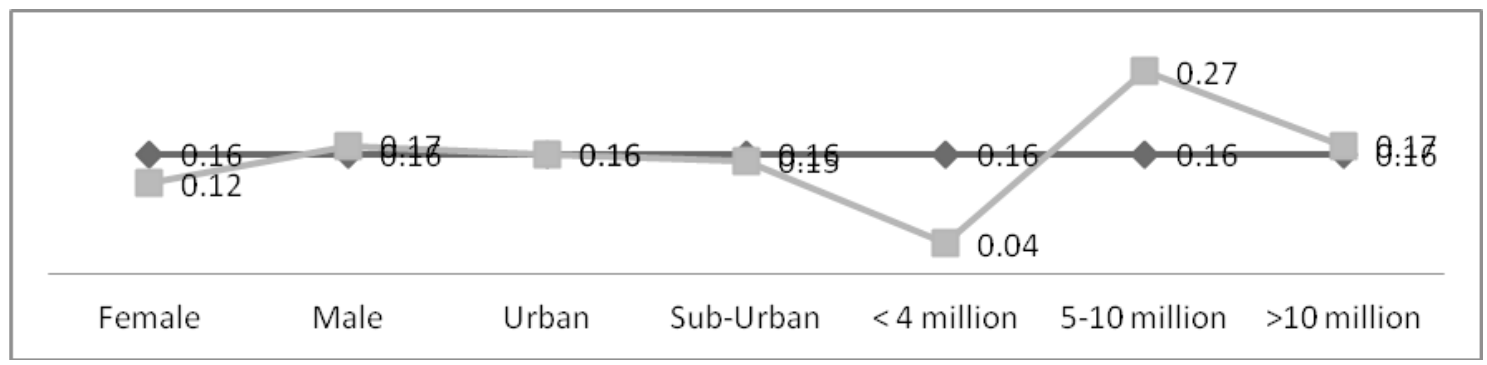

Figure 4.The Relationship Statistic X2 $\rightarrow$ Y

It is known from Table 2 that moderation based on sex is divided into female and male, based on location is divided into urban and sub urban, while based on income is divided into $<4$ million, 5-10 million and $>10$ million. Generally, it is known that the correlation of green perceived value $(\mathrm{X} 1)$ on green awareness $(\mathrm{Y})$ is improved, it is seen from customer's characteristic for sex (male), location (urban), income $<4$ million and income $>$ 10 million (Figure 3 ). While for the correlation of green brand attribute (X2) can improve green awareness $(\mathrm{Y})$ through characteristic's support for sex (male), income 5-10 million and income $>10$ million. According to data processing result which is based on support of sex, location, and customer's income seems there is better change on the correlation of green perceived value, green brand attribute on green awareness.

\subsection{Study of Green Perceived Value, Green Brand Attribute and Green Awareness}

The phenomenon happened for customer's green awareness of environmentally friendly products in Indonesia is still low of caring (Alamsyah et al., 2017). But those cases can be controlled by the attention on other customer's behavior which is green perceived value. The 


\section{Jurnal Ekonomi Pembangunan, 18 (2), 2017, 245-255}

research result is found that the value of green perceived value on green awareness improvement is quite higher. It marks that green perceived value can improve customer's green awareness. The correlation between the two of them needs to keep noticed by marketing, when it will improve customer's green awareness. Because the impact of green awareness is very close related to customer's decision in having environmentally friendly products (Suki, 2013).

In green perceived value becomes important to be noticed, it is started from green perceived value such as good value, expectations, environmental concern, environmental friendly, and environmental benefit(Chen \& Chang, 2012). But the most influencing on green perceived value behavior for customer is the opinion of good value, environmental friendly and environmental benefit. Sometimes, customer assumes to do buying green product is considering between price and good value (Lian et al., 2016). It means that the content of green product becomes the important attention in improving green perceived value. While naturally, green product like organic vegetables is truly known with environmental friendly and environmental benefit (Pearson, Henryks, \& Jones, 2011). Through some those point of views can forms well customer's green perceived value on green product.

Besides green perceived value that has also the correlation with green awareness is green brand attribute. Based on study result (Figure 2), it seems that green awareness can improve positively if customer assumes good for green brand attribute from environmental friendly product. Although it is known from the level of importance, green perceived value is more dominated its correlation with green awareness. The characteristic of organic products like organic vegetables that is attached and it is assessed from its attribute side such as expensive, reasonably priced, prestigious, associated with rich owners, telling the time, durable, pure or natural, rich or creamy, and tasty (Bhat \& Reddy, 2001). But the most influencing in forming customer's green brand attribute is durable, telling the time, expensive, pure or natural, and associated with rich owners. Attribute of green product like organic vegetables is actually most known such as durable, where organic is more durable if it is stored well in refrigerator (Parsa, Lord, Putrevu, $\&$ Kreeger, 2015). It relates to chemical materials which are not contained in organic products, so the product will be more durable. From other attributes side is telling the time, it means that consuming green product so it means talking about time. The determining time is time of manufacture and getting product are not easy. Most of customer in Indonesia complains that to get product which is free from chemical materials, is only obtained from supermarket, and it is hard founded in common market (Alamsyah et al., 2017). Nowadays, environmentally friendly product is known as the more expensive product compared with conventional product (Kim \& Chung, 2011). Remember that organic product is produced without chemical materials and it is not disadvantageous for nature (Othman \& Rahman, 2014). The last, the characteristic that is possible felt by customer especially in Indonesia is that organic product only consumed for better social class, because organic product sometimes associated with rich owners (Alamsyah et al., 2017).

Relating to green awareness which finally can be controlled by customer's behavior for green perceived value and it is truly in line with the previous study from Wu \& Chen (2014). While the study for the correlation of green awareness with green brand attribute is in line with the previous study from Purnama \& Nurhadi (2014). It seems partially, there is similarity with previous study, but the study of model as simultaneously has not been reviewed particularly in Indonesia. This finding obviously gives benefit for marketing like supermarket in evaluating customer's green awareness through green perceived value and green brand attribute. From green awareness side, that becomes important attention for customer is consumers' environmental concerns 
and awareness of brand image. Those cases are surely need to be noticed from marketing side which is supermarket in marketing strategy with observing green awareness's behaviour.

\subsection{Moderation of Sex, Location, and Income}

It has been known in the review of research results that sex, location, and income from customer have support on the correlation of green perceived value and green brand attribute with green awareness. Those finding become important to be noticed for a marketer, because in approaching customer especially for environmentally friendly product, customer's characteristic is very sensitive (Alamsyah et al., 2017). From sex is known that male is more supportive customer behavior on environmentally friendly product, it seems from the value of statistical comparison is up from the value of correlation standard (Figure 3, Figure 4). It is very interesting because it is commonly to care about organic product is female, it relates to habit as a household (Sandalidou, Baourakis, \& Siskos, 2002). But, the finding of this study is actually male more caring about environmentally friendly products for the case in supermarket. The second moderation is seen from customer's condition which is urban location and it is in sub urban. If it is seen from the previous statistical value (Figure 3, Figure 4), it seems that location condition that is in urban more supportive to the correlation of green perceived value and green brand attribute with green awareness. Customer who is in urban get easier in reaching supermarket (Alamsyah et al., 2017), and especially location from supermarket is dominated in urban, so support from customer's location is encouraging customer behavior on environmentally friendly products particularly for organic product.

Environmentally friendly product is organic product that has different characteristic, in this case is more expensive than conventional product (Bobe, Procopie, Pamfilie, \& Toma, 2014). It means that customer is prosecuted to do more effort in buying. So customer from better social status dominates in organic product selection (Haghjou et al., 2013). Those reviews are in line with the finding from support of customer's demographic which based on income. Actually, the correlation of green perceived value and green brand attribute with green awareness becomes better when customer's income also be better. When customer who has income $>10$ million actually has character that supports customer's behavior on environmentally friendly product. From green perceived value side, the correlation value with green awareness is up to the average, also from green brand attribute side (Figure 3, Figure 4). It is different with customer's character that has income for 5-10 million, in which it is more supportive from green perceived value side. It seems from all of reviews for moderation of sex, location, and income truly encourage the correlation of green perceived value and green brand attribute with green awareness. It needs to become attention for marketers in determining the deeper marketing strategy which based on customer's demographic.

\section{Conclusions}

Research finding has explained that green perceived value and green brand attribute are good antecedent for green awareness. The influence of green perceived value is better on green brand attribute, because customer's view for the whole characteristics of environmentally friendly products always become the major attention for customer. Currently, customer assumes to be more important for good value, environmental friendly and environmental benefit. Those cases become the important consideration in form of customer's green perceived value for environmentally friendly products. While from the side of green brand attribute that becomes attention is durable, telling the time, expensive, pure or natural, and associated with rich owners. The last, the most important behavior from green awareness as the major goals of this study is customer's characteristic from consumers' environmental 
concerns and awareness of brand image. Some of customer's characteristic for environmentally friendly product is surely ease the seller from supermarket in understanding characteristic or customer behaviour on environmentally friendly products and adjusting with its marketing strategy.

The correlation of green perceived value and green brand attribute with green awareness are truly more improving with support from customer's demographic which is observed from sex, customer's location and income. Male is actually more dominant to understand environmentally friendly products than female. From side of location, the location in urban becomes better in encouraging to customer does selection from environmentally friendly products. While the income side, the major target is obviously customer who has better buying interest. Because green product is selected not only they understand but also financial support influences their behaviour. This study is not deepening the review of others customer's behaviour that has role for customer's green awareness to be more caring of environmentally friendly products. Thus, it is suggested for next research notices from green advertising side (Suki et al., 2016), green brand image (Suki, 2013) and company social responsibility (Alamsyah \& Hariyanto, 2017).

\section{References}

Alamsyah, D. P., \& Hariyanto, O. I. B. (2017). Store image of organic product: Social responsibility and trust's mediator. In Cyber and IT Service Management (CITSM), 2017 5th International Conference (pp. 1-4). IEEE.

Alamsyah, D. P., Trijumansyah, A., \& Hariyanto, O. I. B. (2017). Mediating of Store Image on Customer Trust for Organic Vegetables. MIMBAR, Jurnal Sosial Dan Pembangunan, 33(1).

Ariffin, S., Yusof, J. M., Putit, L., \& Shah, M. I.
A. (2016). Factors Influencing Perceived Quality and Repurchase Intention Towards Green Products. Procedia Economics and Finance, 37(16), 391-396.

Atănăsoaie, G. S. (2013). Eco-Label and its Role in the Development of Organic Products Market. Economy Transdisciplinarity Cognition, 16(1), 122-129.

Bhat, S., \& Reddy, S. K. (2001). The impact of parent brand attribute associations and affect on brand extension evaluation. Journal of Business Research, 53, 111-122.

Bobe, M., Procopie, R., Pamfilie, R., \& Toma, M. A. (2014). Producer's responsibility concerning the assurance and statement of quality for foods with "organic image" based on the model of a Romanian company. Amfiteatru Economic, 16(35), 215-227.

Chen, Y., \& Chang, C. (2012). Enhance Green Purchase Intentions. The Roles of Green Perceived Value, Green Perceived Risk, and Green Trust. Management Decision, 50(3), 502-520.

Chi, H. K., Yeh, H. R., \& Jang, B. F. (2008). The Effects of Service Quality, Customer Perceived Value, Customer Satisfaction on Behavioral Intentions: A Study of Mobile Value-Added Services in Taiwan. The Business Review Cambridge, 10(1), 129-136.

Ellison, B., Duff, B. R. L., Wang, Z., \& White, T. B. (2016). Putting the organic label in context: Examining the interactions between the organic label, product type, and retail outlet. Food Quality and Preference, 49, 140-150. http://doi.org/10.1016/j.foodqual.2015.11.013

Haghjou, M., Hayati, B., Pishbahar, E., Mohammadrezaei, R., \& Dashti, G. (2013). Factors affecting consumers' potential willingness to pay for organic food products in Iran: Case study of Tabriz. Journal of Agricultural Science and Technology, 15(2), 191-202.

Keller, K. L. (1993). Conceptualizing, Measuring, 
Jurnal Ekonomi Pembangunan, 18 (2), 2017, 245-255

and Managing Customer-Based Brand Equity. Journal of Marketing, 57(1), 1. http:// doi.org/10.2307/1252054

Khor, K. S., Udin, Z. M., Ramayah, T., \& Hazen, B. T. (2016). Reverse logistics in Malaysia: The Contingent role of institutional pressure. International Journal of Production Economics, 175, 96-108. http://doi. org/10.1016/j.ijpe.2016.01.020

Kim, H. Y., \& Chung, J.-E. (2011). Consumer Purchase Intention For Organic Personal Care Products. Journal of Consumer Marketing, 28(1), 40-47.

Lassoued, R., \& Hobbs, J. E. (2015). Consumer Confidence in Credence Attributes: The Role of Brand Trust. Food Policy, 52, 99-107. http://doi.org/10.1016/j.foodpol.2014.12.003

Lian, S. B., Safari, M., \& Mansori, S. (2016). The effects of marketing stimuli factors on consumers' perceived value and purchase of organic food in Malaysia. Jurnal Pengurusan, 47, 119-130.

Mourad, M., Serag, Y., \& Ahmed, E. (2012). Perception of green brand in an emerging innovative market. European Journal of Innovation Management, 15(4), 514-537. http:// doi.org/10.1108/14601061211272402

Nadzri, W. N. M., Musa, R., Muda, M., \& Hassan, F. (2016). The Antecedents of Brand Experience within the National Automotive Industry. Procedia Economics and Finance, 37(16), 317-323. http://doi.org/10.1016/ S2212-5671(16)30131-9

Nikhashemi, S. R., Tarofder, A. K., Gaur, S. S., \& Haque, A. (2016). The Effect of Customers' Perceived Value of Retail Store on Relationship between Store Attribute and Customer Brand Loyalty: Some Insights from Malaysia. Procedia Economics and Finance, 37(16), 432-438. http://doi.org/10.1016/ S2212-5671(16)30148-4

Othman, C., \& Rahman, M. S. (2014). Investigation of the Relationship of Brand Personal- ity, Subjective Norm and Perceived Control on Consumers' Purchase Intention of Organic Fast Food. Modern Applied Science, 8(3), 92-106.

Parsa, H. G., Lord, K. R., Putrevu, S., \& Kreeger, J. (2015). Corporate social and environmental responsibility in services: Will consumers pay for it? Journal of Retailing and Consumer Services, 22, 250-260. http://doi. org/10.1016/j.jretconser.2014.08.006

Pearson, D., Henryks, J., \& Jones, H. (2011). Organic food: What we know (and do not know) about consumers. Renewable Agriculture and Food Systems, 26(2), 171-177. http://doi.org/10.1017/S1742170510000499

Purnama, J., \& Nurhadi. (2014). Pengaruh Produk Ramah Lingkungan, Atribut Merek Hijau, Iklan Peduli Lingkungan Dan Persepsi Harga Premium Terhadap Keputusan Pembelian Produk AMDK. Jurnal Fakultas Ekonomi, (5), 1-9.

Rahmi, D. Y., Rozalia, Y., Chan, D. N., Anira, Q., \& Lita, R. P. (2017). Green Brand Image Relation Model, Green Awareness, Green Advertisement, and Ecological Knowledge as Competitive Advantage in Improving Green Purchase Intention and Green Purchase Behavior on Creative Industry Products. Journal of Economics, Business \& Accountancy Ventura, 20(2). http://doi. org/10.14414/jebav.v20i2.1126

Rizwan, M., Mahmood, U., Siddiqui, H., \& Tahir, A. (2014). An Empirical Study about Green Purchase Intentions. Journal of Sociological Research ISSN Journal of Sociological Research, 5(1), 290-305. http://doi. org/10.5296/

Sandalidou, E., Baourakis, G., \& Siskos, Y. (2002). Customers' perspectives on the quality of organic olive oil in Greece: A satisfaction evaluation approach. British Food Journal, 104(3/4/5), 391-406. http://doi. org/10.1108/00070700210425787 
Shaharudin, M. R., Pani, J. J., Mansor, S. W., \& Elias, S. J. (2010). Factors Affecting Purchase Intention of Organic Food in Malaysia's Kedah State. Cross-Cultural Communication, 6(2), 105-116.

Suki, N. M. (2013). Green awareness effects on consumers' purchasing decision: Some insights from Malaysia. International Journal of Asia-Pacific Studies, 9(2), 49-63.

Suki, N. M., Suki, N. M., \& Azman, N. S. (2016). Impacts of Corporate Social Responsibility on the Links Between Green Marketing Awareness and Consumer Purchase Intentions. Procedia Economics and Finance, 37(16), 262-268. http://doi.org/10.1016/ S2212-5671(16)30123-X

Syarifuddin, D. (2016). Nilai Wisata Budaya Seni Pertunjukan Saung Angklung Udjo Kota Bandung Jawa Barat Indonesia. Jurnal Manajemen Resort Dan Leisure, 13(2), 5360.
Syarifuddin, D. (2017). Competitive Advantage on Hotel Industry in Pekanbaru Indonesia. Internasional Business Management, 11(2), 397-406.

Wirth, F. F., Stanton, J. L., \& Wiley, J. B. (2011). The Relative Importance of Search Versus Credence Product Attributes: Organic and Locally Grown. Agricultural and Resource Economics Review, 40(1), 48-62.

Wu, S., \& Chen, Y. (2014). The Impact of Green Marketing and Perceived Innovation on Purchase Intention for Green Products. International Journal of Marketing Studies, 6(5), 81-101. http://doi.org/10.5539/ijms. v6n5p81

Yoo, S. J., \& Chang, Y. J. (2005). An Exploratory Research on the Store Image Attributes Affecting Its Store Loyalty. Seoul Journal of Business, 11(1), 19-41. 